\title{
Presentation of COVID-19 infection with bizarre behavior and encephalopathy: a case report
}

\author{
Zahra Teimouri-Jervekani ${ }^{1}$ and Mehrzad Salmasi ${ }^{2^{*}}$
}

\begin{abstract}
Background: Current studies show that patients with severe coronavirus disease 2019 (COVID-19) have neurological symptoms manifesting as acute cerebrovascular diseases, impaired consciousness, and skeletal muscle symptoms. Bizarre behavior is an unusual and unique presenting symptom of COVID-19 infection in our patient.

Case presentation: We report a case of COVID-19 infection in a middle aged Iranian man without underlying disease who presented with bizarre behavior. Results of brain imaging were normal, but COVID-19 pneumonia was detected on chest computed tomography scan. Given the respiratory problem and positive polymerase chain reaction (PCR) test for COVID-19, treatment with hydroxychloroquine was administered, and after 2 days all of the symptoms resolved.
\end{abstract}

Conclusions: Encephalopathy and encephalitis may be a possible presentation of COVID-19. Clinicians and health care providers should consider the presence of COVID-19 with bizarre behavior during this COVID-19 pandemic.

Keywords: COVID-19, Encephalopathy, Bizarre behavior

\section{Background}

In December 2019, Wuhan, in Hubei province, China, became the center of an outbreak of coronavirus disease 2019 (COVID-19)-induced pneumonia [1]. This disease was diagnosed for the first time in Iran in February 2020, and the coronavirus outbreak then increased rapidly [2].

COVID-19 infection has a wide spectrum of clinical symptoms including asymptomatic infection, mild and severe forms of respiratory problems, and even death due to respiratory failure [3].

Current studies show that patients with severe COVID19 have neurological symptoms manifesting as acute cerebrovascular diseases, impaired consciousness, and skeletal muscle symptoms [4]. Altered mental status can

*Correspondence: mehrzad_salmasi@yahoo.com

${ }^{2}$ Internal Medicine Department, Isfahan University of Medical Sciences, Isfahan, Iran

Full list of author information is available at the end of the article be the presenting symptom of COVID-19 infection in older patients. One case of encephalopathy was reported in a 72-year-old man with underlying disease who was infected with COVID-19 [5].

Here we report a case of COVID-19 infection in a middle-aged man who presented with encephalopathy. This study was approved by the ethics committee of Isfahan University of Medical Sciences (IR.MUI.MED. REC.1399.913).

\section{Case presentation}

A 53 year old Iranian man without any past medical history presented to the emergency department with symptoms of severe headache and bizarre behavior. Symptom onset occurred 2 weeks before admission; the first symptoms were fever and myalgia. The fever lasted 3 days, and then cough and dyspnea appeared. With the progression of dyspnea, the patient experienced some episodes of severe generalized headache. The headache became original author(s) and the source, provide a link to the Creative Commons licence, and indicate if changes were made. The images or other third party material in this article are included in the article's Creative Commons licence, unless indicated otherwise in a credit line to the material. If material is not included in the article's Creative Commons licence and your intended use is not permitted by statutory regulation or exceeds the permitted use, you will need to obtain permission directly from the copyright holder. To view a copy of this licence, visit http://creativecommons.org/licenses/by/4.0/. The Creative Commons Public Domain Dedication waiver (http://creativeco mmons.org/publicdomain/zero/1.0/) applies to the data made available in this article, unless otherwise stated in a credit line to the data. 
progressively worse, and on the day of his admission, he exhibited bizarre behavior. For example, he undressed, removing his shirt and trousers, in front of his family and also tried to urinate in the room. Due to the appearance of dysarthria that morning and other problems, he was admitted to the emergency department. He had no specific family or social history. On physical exam, except for dysarthria, he had normal vital signs, no sign of hypoxia, and normal neurological exam. The patient was alert and oriented to time, place, and person. No neck stiffness, Kernig's sign, or Brudzinski's sign was detected.

Routine laboratory tests and chest and brain computed tomography $(\mathrm{CT})$ were performed. Laboratory test results are summarized in Table 1 . Chest $\mathrm{CT}$ revealed

Table 1 Laboratory tests

\begin{tabular}{|c|c|c|}
\hline White blood cells/ $\mu \mathrm{L}$ & 8700 & $4000-10000$ \\
\hline Hemoglobin g/dL & 14.6 & $14-18$ \\
\hline Platelets/ $\mu \mathrm{L}$ & $353 \times 10^{3}$ & $150-450 \times 10^{3}$ \\
\hline Lymphocytes \% & 11.1 & \\
\hline Neutrophils \% & 83 & \\
\hline Erythrocyte sedimentation rate $\mathrm{mm} /$ hour & 67 & $0-12$ \\
\hline C-reactive protein mg/L & 12 & $0-6$ \\
\hline Blood urea nitrogen $\mathrm{mg} / \mathrm{dL}$ & 24 & $8.4-25.7$ \\
\hline Creatinine $\mathrm{mg} / \mathrm{dL}$ & 0.81 & $0.7-1.4$ \\
\hline Sodium mEq/L & 144 & $135-145$ \\
\hline Potassium $\mathrm{mEq} / \mathrm{L}$ & 4 & $3.8-5$ \\
\hline Magnesium mEq/L & 2.2 & $1.8-2.6$ \\
\hline Calcium mg/dL & 8.56 & $8.5-11$ \\
\hline Phosphorus mg/dL & 2.88 & $2.6-4.5$ \\
\hline Albumin $\mathrm{g} / \mathrm{dL}$ & 4.2 & $3.5-5.2$ \\
\hline Aspartate aminotransferase $\mathrm{U} / \mathrm{L}$ & 27 & $0-38$ \\
\hline Alanine aminotransferase $\mathrm{U} / \mathrm{L}$ & 16 & $0-41$ \\
\hline Alkaline phosphatase $U / L$ & 124 & $80-306$ \\
\hline $\mathrm{pH}$ & 7.33 & \\
\hline $\mathrm{PCO}_{2} \mathrm{mmHg}$ & 37.2 & \\
\hline $\mathrm{HCO}_{3} \mathrm{mEq} / \mathrm{L}$ & 19.6 & \\
\hline Creatine phosphokinase IU/L & 100 & $21-232$ \\
\hline Glucose mg/dL & 96 & $70-115$ \\
\hline COVID-19 RT-PCR & Positive & \\
\hline Blood culture & Negative & \\
\hline Toxin panel & $\begin{array}{l}\text { Negative for opioids, amphetamine and methamphetamine, tricyclic } \\
\text { antidepressants, benzodiazepine }\end{array}$ & \\
\hline Urinalysis & Normal & \\
\hline
\end{tabular}

$\mathrm{PCO}_{2}$ partial pressure of carbon dioxide, $\mathrm{HCO}_{3}$ bicarbonate, $\mathrm{RT}-\mathrm{PCR}$ reverse transcription polymerase chain reaction

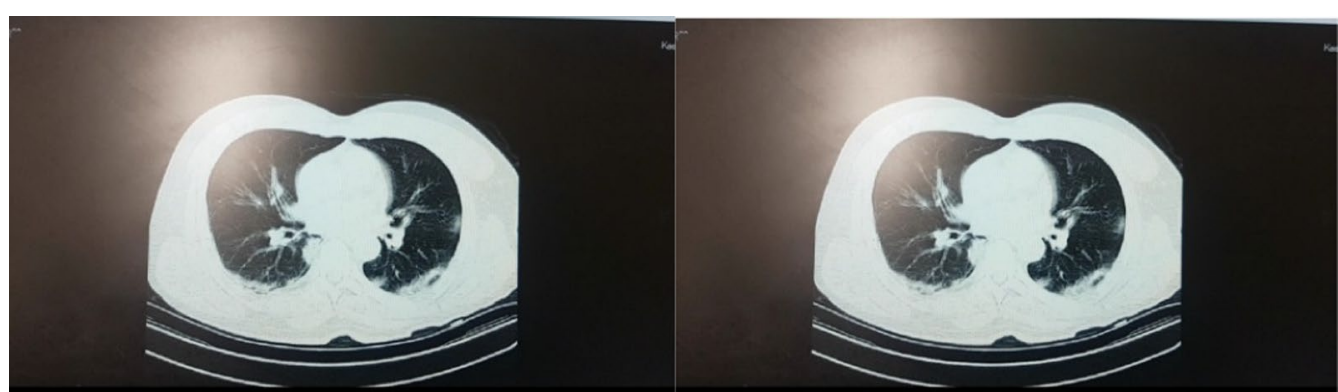

Fig. 1 Lung high-resolution computed tomography 


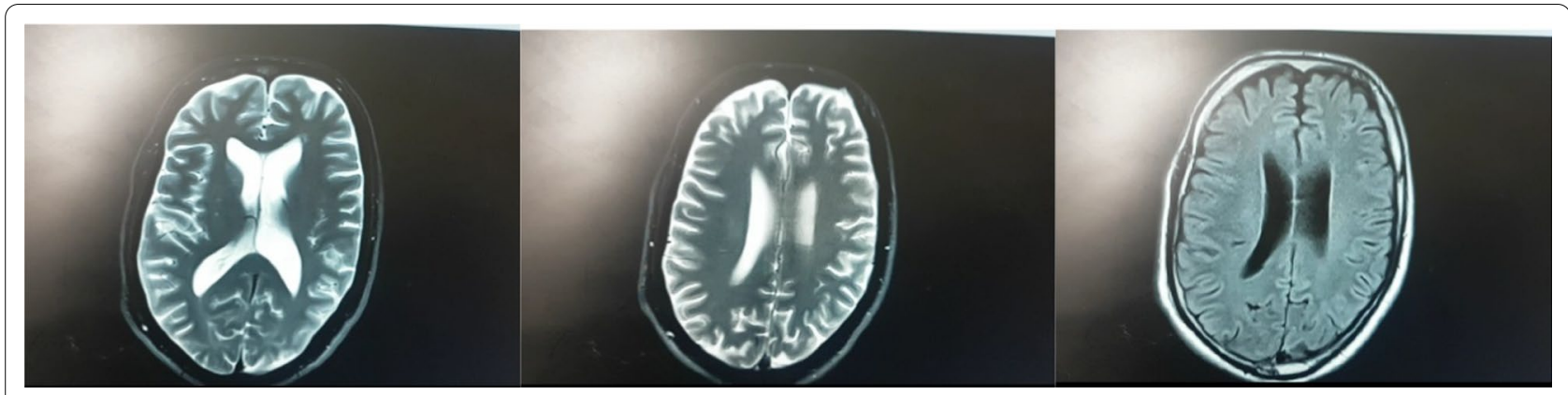

Fig. 2 Brain magnetic resonance imaging with diffusion-weighted imaging

bilateral peripheral ground-glass opacities suggestive of COVID-19 infection (Fig. 1).

Due to normal brain CT results, brain magnetic resonance imaging (MRI) was performed to evaluate the cause of dysarthria and bizarre behavior (Fig. 2). The brain MRI results were normal.

Based on the respiratory problem and positive polymerase chain reaction (PCR) test for COVID-19, the patient was treated with hydroxychloroquine (200 mg twice daily for 5 days). After 2 days, dysarthria and abnormal behavior were resolved completely. The patient was discharged on day 4, with resolution of respiratory and neurological signs and symptoms.

\section{Discussion}

The signs and symptoms of COVID-19 present at illness onset vary from mild or nonspecific symptoms to severe respiratory distress, and non-respiratory symptoms have also been reported [6]. Common neurological manifestations reported for COVID-19 are acute stroke, impaired consciousness, and muscle injury. Patients with severe cases and older patients are more susceptible to these complications [4]. In light of the lack of sufficient data on COVID-19, a review of past experience with neurological aspects of previous forms of coronavirus was carried out. Although the data are sparse, rare cases of acute disseminated encephalomyelitis (ADEM)-like demyelination, encephalitis, and brainstem encephalitis have been reported for Middle East respiratory syndrome (MERS), severe acute respiratory syndrome (SARS), and other types [7-10]. One report described a case of encephalopathy in a 72-year-old man with underlying neurological disease who was infected with COVID-19 [4]. The severe acute respiratory syndrome coronavirus 2 (SARS$\mathrm{CoV}-2$ ) invades the brain by various routes, such as binding to the ACE2 receptor on neurons and endothelial cells, through the olfactory system and spread across the cribriform plate, and by crossing the blood-brain barrier via infected leukocyte migration by a Trojan horse mechanism. Encephalopathy is reported in older patients and patients with severe or critical disease [11-13]. Our patient was middle-aged, without any previous medical history, and with normal brain imaging and nonsevere infection. Due to the relatively rapid resolution of neurological symptoms and no pathological findings in the imaging, further studies were not performed. The etiology of encephalopathy or possible encephalitis in COVID-19 or other coronaviruses remains poorly understood, and could be due to misdirected host immune responses [14]. Neurological manifestations of COVID19 derive from both direct invasion and indirect effects due to hyperinflammation and encephalopathy [15]. As the number of patients with COVID-19 increases worldwide, clinicians should be watchful for patients presenting with bizarre behavior or altered mental status. Possible spread from the respiratory tract to the central nervous system must be considered, and cerebrospinal fluid analysis for virus detection is recommended in similar cases to determine whether a direct viral infection is responsible for the clinical presentations or immune system response.

\section{Conclusions}

Encephalopathy and encephalitis may be a presentation of COVID-19. Clinicians and health care providers should consider the presence of COVID-19 in patients with bizarre behavior even in non-severe forms of the disease during this pandemic.

\section{Acknowledgements \\ Isfahan University of Medical Sciences (scientific code of study: 199518).}

\section{Authors' contributions}

MS and ZT contributed to the conception of the work, writing and editing of the manuscript, and critical revision. Both authors read and approved the final manuscript.

\section{Funding}

Not applicable. 
Availability of supporting data

Not applicable.

\section{Declarations}

\section{Ethics approval and consent to participate}

This case report was approved by ethical committee of Isfahan University of Medical Science. (IR.MUI.MED.REC.1399.913).

\section{Consent for publication}

Written informed consent was obtained from the patient for publication of this case report and any accompanying images. A copy of the written consent is available for review by the Editor-in-Chief of this journal.

\section{Competing interests}

The authors declare that they have no competing interests.

\section{Author details}

${ }^{1}$ Cardiac Rehabilitation Center, Cardiovascular Research Institute, Isfahan University of Medical Sciences, Isfahan, Iran. ${ }^{2}$ Internal Medicine Department, Isfahan University of Medical Sciences, Isfahan, Iran.

Received: 20 May 2020 Accepted: 5 April 2021

Published online: 28 April 2021

\section{References}

1. Phelan AL, Katz R, Gostin LO. The novel coronavirus originating in Wuhan, China: challenges for global health governance. JAMA. 2020;323(8):709-10.

2. https://www.worldometers.info/coronavirus/feb-2020-news-updatescovid19/. Accessed Feb 2021.

3. Huang C, Wang Y, Li X, et al. Clinical features of patients infected with 2019 novel coronavirus in Wuhan, China. Lancet. 2020;395:497-506.

4. Mao L, Jin H, Wang M, Hu Y, Chen S, He Q, Chang J, Hong C, Zhou Y, Wang D, Miao X. Neurologic manifestations of hospitalized patients with coronavirus disease 2019 in Wuhan, China. JAMA Neurol. 2020;77(6):683-90
5. Filatov A, Sharma P, Hindi F, Espinosa PS. Neurological complications of coronavirus disease (COVID-19): encephalopathy. Cureus. 2020;12(3).

6. Chen J, Qi T, Liu L, Ling Y, Qian Z, Li T, Li F, Xu Q, Zhang Y, Xu S, Song Z. Clinical progression of patients with COVID-19 in Shanghai, China. J Infect. 2020;80(5):e1-6.

7. Morfopoulou S, Brown JR, Davies EG, Anderson G, Virasami A, Qasim W, Chong WK, Hubank M, Plagnol V, Desforges M, Jacques TS. Human coronavirus OC43 associated with fatal encephalitis. N Engl J Med. 2016:375(5):497-8.

8. Li Y, Li H, Fan R, Wen B, Zhang J, Cao X, Wang C, Song Z, Li S, Li X, LV $X$. Coronavirus infections in the central nervous system and respiratory tract show distinct features in hospitalized children. Intervirology 2016:59(3):163-9.

9. Netland J, Meyerholz DK, Moore S, Cassell M, Perlman S. Severe acute respiratory syndrome coronavirus infection causes neuronal death in the absence of encephalitis in mice transgenic for human ACE2. J Virol. 2008;82(15):7264-75.

10. Schattner A, Hadar S, Dubin I. Human coronavirus NL63 and acute encephalitis. Ann Infect Dis Epidemiol. 2018;3(2):1032.

11. Li MY, Li L, Zhang Y, Wang XS. Expression of the SARS-CoV-2 cell receptor gene ACE2 in a wide variety of human tissues. Infect Dis Poverty. 2020;9(1):45.

12. Puelles VG, Lütgehetmann M, Lindenmeyer MT, Sperhake JP, Wong MN, Allweiss L, Chilla S, Heinemann A, Wanner N, Liu S, Braun F. Multiorgan and renal tropism of SARS-CoV-2. N Engl J Med. 2020;383(6):590-2.

13. Garg RK, Paliwal VK, Gupta A. Encephalopathy in patients with COVID-19: a review. J Med Virol. 2021:93(1):206-22.

14. Desforges M, Le Coupanec A, Stodola JK, Meessen-Pinard M, Talbot PJ. Human coronaviruses: viral and cellular factors involved in neuroinvasiveness and neuropathogenesis. Virus Res. 2014;19(194):145-58.

15. Jasti M, Nalleballe K, Dandu V, Onteddu S. A review of pathophysiology and neuropsychiatric manifestations of COVID-19. J Neurol. 2020;3:1.

\section{Publisher's Note}

Springer Nature remains neutral with regard to jurisdictional claims in published maps and institutional affiliations.
Ready to submit your research? Choose BMC and benefit from:

- fast, convenient online submission

- thorough peer review by experienced researchers in your field

- rapid publication on acceptance

- support for research data, including large and complex data types

- gold Open Access which fosters wider collaboration and increased citations

- maximum visibility for your research: over $100 \mathrm{M}$ website views per year

At $\mathrm{BMC}$, research is always in progress.

Learn more biomedcentral.com/submissions 